\title{
The Internationalization of Ethnic Chinese Business Firms from Southeast Asia: Strategies, Processes and Competitive Advantage*
}

\author{
HENRY WAI-CHUNG YEUNG
}

The strongest overseas Chinese have huge conglomerates with global reach. This is not some quaint ethnic sideshow; the Overseas Chinese are increasingly the main event in Asian business today (Kraar, 1993: 87).

\section{Introduction}

The globalization of economic activities is a relatively recent phenomenon. Since the 1960s, the global economy has become increasingly interdependent and functionally integrated through cross-border flows of capital, goods and people. The role of transnational corporations (TNCs) in these cross-border activities is particularly important. The outward foreign direct investment (FDI) stock of TNCs grew from a meagre US\$129 billion in 1970 to US\$1,146 billion in 1988 (UNCTAD, 1994: Table I.8). By the end of 1995, there were some 39,000 TNCs in the world, which controlled more than 270,000 foreign affiliates. They had a combined outward FDI stock of more than US\$2.7 trillion (UNCTAD, 1996). The outcomes of this accelerated process of globalization are manifested in the increasing global interdependence of national economies and Triadization. In the former case, the economic fortunes of countries are intertwined with the global shift of economic activities (Dicken, 1998). In the latter, three distinct regions have emerged as the leading centres of the global economy - North America, western Europe and Asia (Ohmae, 1985; 1995).

In recent decades, Chinese business in Southeast Asia has similarly undergone significant transformations. From petty traders and emigrant workers in the early half of the twentieth century, the 'Overseas Chinese' and their business firms have emerged as

\footnotetext{
* This is a revised version of an earlier paper presented at the Chinese Business in Southeast Asia Conference, Kuala Lumpur, 23-25 June 1997. I am grateful to K.S. Jomo, Raj Brown, Terence Gomez, Jamie Mackie, Donald Nonini, Carl Trocki, Souchou Yao and an anonymous IJURR referee for their insightful comments. Kris Olds and Peter Dicken have also offered helpful suggestions on various occasions. Some of the materials used in this paper are collected as part of an ongoing research project on the regionalization of Singaporean firms funded by the National University of Singapore (RP960045 and RP970013). All errors and mistakes, however, are my own responsibility.
} 
one of the most important economic forces in many Southeast Asian countries. ${ }^{1}$ Today, the 'Overseas Chinese' control some $80 \%$ of corporate assets and 160 of the 200 largest enterprises in Indonesia; 40-50\% of corporate assets in Malaysia; $90 \%$ of manufacturing and 50\% of services in Thailand (Wu and Duk, 1995; Weidenbaum and Hughes, 1996). In 1995, every reported Indonesian billionaire was an ethnic Chinese. In Thailand, the 'Overseas Chinese' control the four largest private banks, of which Bangkok Bank is the largest and most profitable in the region. In the Philippines, the 'Overseas Chinese control over one-third of the 1000 largest corporations. The World Bank estimates that the combined economic output of the 'Overseas Chinese' was about US\$400 billion in 1991 and US\$600 billion by 1996 (Weidenbaum and Hughes, 1996: 25). The collective 'funds' of the 'Overseas Chinese' in the region (excluding Hong Kong and Taiwan) are conservatively estimated at US\$400 billion (Hodder, 1996: 3). With these strong footholds in local industries and capital markets, many Chinese business groups from Southeast Asia are increasingly establishing operations outside their 'home' countries. As such, these Chinese business firms have entered a new era of their corporate development - internationalization to establish and consolidate the worldwide web of Chinese business (see also Kao, 1993). Internationalization is defined as a process of cross-border operations when a business firm headquartered in one country controls and influences the strategic decision-making of at least one affiliate in another country. When a Chinese business firm from any Southeast Asian country controls and operates at least one affiliate in another country within or outside the region, it is defined as a transnational corporation (TNC).

Although the internationalization tendencies of Chinese business firms are recent in origin, it is rather surprising to learn that they remain relatively under-researched in at least two presumably very relevant strands of literature: (1) the 'third world multinationals' literature; (2) the 'Overseas Chinese' literature. The first strand of literature is dominated by economics and international business studies (e.g. Kumar and McLeod, 1981; Lall, 1983; Wells, 1983; Khan, 1986; Tolentino, 1993; Yeung, 1999a; Aggarwal, forthcoming). To date, most empirical studies in this literature concentrate on the characteristics and explanatory factors of the internationalization of TNCs from the 'third world'. Because of an overtly economistic explanatory matrix, these studies tend to relate the motivations of these 'third-world multinationals' to economic conditions of home and host countries, ignoring the social and cultural dimensions of firm behaviour and, by extension, the ethnicity dimension of these business firms (Yeung, 1994a). The second strand of literature, on the other hand, is preoccupied with the 'Overseas Chinese' in their domestic setting and their success in establishing themselves in the host countries (e.g. Chen, 1976; Lim and Gosling, 1983; Goldberg, 1985; Limlingan, 1986; Jesudason, 1989; Redding, 1990; Menkhoff, 1993; Chan and Chiang, 1994; Brown, 1995; East Asia Analytical Unit, 1995; Hodder, 1996). It is less concerned with the transnational operations of ethnic Chinese business firms. This is surprising since some Chinese business firms have been engaging in cross-border operations since the turn of the century (e.g. the Wing On Company now based in Hong Kong; see Chan, 1995). It is only in the past few years that empirical studies of the internationalization of Chinese business begin to surface (e.g. Smart and Smart, 1991; Kao, 1993; Mitchell, 1995; Van Den Bulcke and Zhang, 1995; Hsing, 1997; Yeung, 1997a; 1997b; Olds, 1999; Olds and Yeung, 1999; Yeung and Olds, 1999).

Against these intellectual contexts, this paper aims to make a modest contribution to the literature by offering a preliminary examination of the nature and organization of ethnic Chinese business firms from Southeast Asia when they internationalize into foreign lands. It focuses on their firm-specific strategies and processes of internationa-

1 Notwithstanding the problematic nature of the term 'Overseas Chinese' (see Hodder, 1996), I am using it as an umbrella term to refer to those residents in Southeast Asia having Chinese origins. 
lization as well as home-based competitive advantages in establishing themselves abroad. The underlying argument is that the internationalization of ethnic Chinese business firms from Southeast Asia can be explained by considering an amalgamation of multidimensional dynamic processes and therefore cannot be narrowed down to any single factor. In explaining the internationalization of these Chinese business firms, we need to pay as much attention to their firm-specific strategies as to the changing global and regional contexts in which these business firms are embedded and their strategies are implemented. More specifically, some unique features of their internationalization strategies can be highlighted here: (1) sectoral specialization through vertical integration; (2) diversification into unrelated businesses; and (3) family ownership and management. These internationalization strategies of Chinese business firms are prompted by increasing pressures from the accelerated globalization of economic activities because (1) they face more competition from global players domestically; (2) their home markets are becoming more saturated; (3) their home-based competitive advantages dissipate quickly through deregulation and (4) their family successors are more outward-looking in business practices and opportunity-seeking. Together, it can be argued that through their international business activities, Chinese business firms from Southeast Asia are becoming an increasingly important force in the regional economy. In methodological terms, this paper is empirically based on several existing case studies of major ethnic Chinese-controlled conglomerates from Southeast Asia. This is a second-best solution as empirical materials on Chinese business firms in Southeast Asia are relatively limited.

The paper is organized into three major sections. The next section examines the changing dynamics of Chinese business firms from Southeast Asia. It seeks to discuss the changing global, regional and national contexts which prompt the internationalization of these business firms. The second section analyses the internationalization strategies and processes of these Chinese business firms. It attempts to link these strategies and processes to the changing contexts of global competition and national institutions. The penultimate section offers some insight into the competitive advantage of Chinese business firms from Southeast Asia. The central thesis is that their competitive advantage is embedded in both cultural traditions and political-economic practices. Neither cultural nor political explanations alone can explain fully the foundation of their competitive advantage. The concluding section summarizes the main observations of this paper and suggests some possible areas for a future research agenda.

\section{Changing dynamics of Chinese business firms from Southeast Asia}

The emergence of ethnic Chinese business firms in Southeast Asia is largely associated with the 'Overseas Chinese Diaspora' in Indonesia, Malaysia, Thailand, Singapore and, to a lesser extent, the Philippines (Lim and Gosling, 1983). It must be noted, however, that these ethnic Chinese business firms are generally not the same firms as their predecessors a few decades ago. During their early existence in the twentieth century, Chinese business firms focused predominantly on domestic operations. Their business strategies and management structures were very much influenced by traditional practices 'imported' from China (Limlingan, 1986). Several studies have confirmed the capabilities of these Chinese business firms in establishing themselves in their domestic settings (e.g. McVey, 1992; Menkhoff, 1993; Brown, 1995; East Asia Analytical Unit, 1995; Hodder, 1996). The broader context within which these firms and their firm-specific strategies are embedded, nevertheless, is by no means static. Rather, the changing configurations of the global competitive context and domestic politics, together with continual evolution of Chinese business firms in Southeast Asia, have set in motion a centrifugal process through which these firms are increasingly establishing themselves beyond their domestic operations. As such, the understanding and explanation of this relatively recent 'global 
reach' of Chinese capitalism cannot be achieved without considering changes in the broader context of global competition and local politics. As argued by Dirlik (1997) and Smart (1997), it is impossible to understand Chinese capitalism without comprehending the dynamics of global capitalism because 'the contemporary discourse on a Chinese Capitalism is an integral aspect of the discourse on Global Capitalism' (Dirlik, 1997: 308).

This section examines recent changes in three arenas which impact significantly on firm-specific strategies and internationalization processes of ethnic Chinese business firms from Southeast Asia. From a geographical point of view, these changes represent the changing contexts of their internationalization at global, regional and national scales. This contextualization is important because previous studies of Chinese business in Southeast Asia tend to examine individual firm behaviour outside the changing contexts in which they are embedded (e.g. Limlingan, 1986; McVey, 1992). This section therefore aims to provide some understanding of the contingent factors prompting the internationalization of Chinese business firms from Southeast Asia.

\section{Emerging global and regional opportunities for Chinese business firms}

Within the Asia Pacific region, the 'Overseas Chinese' and their groups of business firms have made a notable head-start in the internationalization of their diverse range of activities, particularly in recent decades. Their dynamics are supported not only by the emergence of global TNCs per se, but also by the changing market structures and institutional configurations in the home countries and in the region. The opening of China since the late 1970s and the regionalization of markets in North America and western Europe during the 1980s prompted and accelerated the internationalization of Chinese business firms from Southeast Asia. Since the inauguration of the open-door policy in China in 1979, China has experienced remarkable economic growth. The late 1980s witnessed the emergence of the 'Greater China' economic zone in which cross-border investments between Hong Kong and China and between Taiwan and China contributed to greater sub-regional integration between Hong Kong and Taiwan on the one hand and southern China on the other (Chen, 1994; La Croix et al., 1995; Hsiao and So, 1997). One of the leading forces in this process of sub-regional integration is represented by ethnic Chinese TNCs from Hong Kong, Taiwan and Southeast Asian countries (Weidenbaum and Hughes, 1996). The opening of China and the subsequent emergence of the 'Greater China' economic zone have therefore facilitated the regionalization of ethnic Chinese TNCs from Southeast Asia (see case studies below).

Another important trend in the global economy is the regionalization of markets in North America and western Europe (Lévy, 1995). The formation of the North American Free Trade Area (NAFTA) and the single European market in the early 1990s has created unprecedented opportunities for Chinese business firms from Southeast Asia to tap into emerging regional markets and centres of technological innovations in the West. As these emerging ethnic Chinese TNCs have consolidated their footholds in Asia, they begin to penetrate markets in North America and western Europe through foreign production and direct investment rather than trade (see case studies below). This represents an important strategic move for Chinese business firms because in today's interdependent global economy, it is no longer sufficient to rely on exports in order to serve foreign markets. Customers are increasingly more demanding and markets are more volatile than before. This is especially the case for markets in North America and western Europe because of intense competition from domestic and global firms. The establishment of transnational operations has become one of the most important competitive strategies for these Chinese business firms to secure a place in global competition. Why are Chinese business firms from Southeast Asia so keen on engaging in cross-border operations? One of the key answers comes from the changing institutional configurations in their 'home' countries. 


\section{Economic development in Southeast Asia}

Since the late 1970s, many Southeast Asian countries have experienced unprecedented growth in their domestic economies. Table 1 presents some key macro-economic indicators of Southeast Asian countries from 1965-94. 2 During the period 1965-85, Singapore registered the highest average annual growth rate at $7.6 \%$, compared with less than $5 \%$ in the four other countries in the Association of South East Asian Nations (ASEAN). Since 1985, the growth pattern has changed considerably. While Singapore has continued to enjoy relatively high annual growth rates since 1987, Indonesia, Malaysia and Thailand have also experienced accelerated growth and structural transformations. Among all ASEAN countries, Thailand has registered the highest growth rates since 1987, followed closely by Malaysia and Indonesia. ${ }^{3}$

This rosy picture of economic growth in Southeast Asian countries nevertheless masks some important undercurrents which have prompted the outward orientation of Chinese business firms in recent years. Some of these contextual issues are summarized in Table 2. First, despite growth in domestic economies, the lack of sizeable domestic markets free from state intervention and monopolistic domination has hindered further growth of many Chinese business firms. Late industrialization in many developing Southeast Asian countries has limited the scale and size of domestic markets, making it almost impossible to take full advantage of scale economies in many industries, including cement, automobiles and even home appliances (Suehiro, 1985; 1993). In the case of Singapore, market saturation has become a serious threat to the long-term survival of many small- and medium-sized enterprises (SMEs) which are mostly owned by ethnic Chinese. This market saturation is very much a consequence of the domination of the domestic market by foreign TNCs and state-owned enterprises during its industrialization process (Rodan, 1989; Yeung 1998a). To a large extent, the regionalization of Singaporean firms recently can be explained by this problem of market saturation.

Second, there has been a policy shift during the 1980s and 1990s towards a more open and competitive environment in Southeast Asia (Yoshihara, 1994). Many more Southeast Asian countries have begun to pursue export-oriented industrialization since the 1980s. As domestic markets are increasingly open to foreign investment and privatization/deregulation policies are being pursued, the monopolistic advantage and subsidies often enjoyed by some leading ethnic Chinese-controlled conglomerates in these countries dissipate quickly. In response, these giant conglomerates have diversified into overseas operations by establishing new ventures and/or acquiring existing operations complementary to their domestic operations (see case studies below).

Third, and perhaps most importantly, anti-Chinese sentiments remain strong and pervasive in the political cultures and public discourses of many Southeast Asian countries (Table 2; also Yoshihara, 1994; Lim, 1996; Yeung, 1997a). In much postindependence Southeast Asia, anti-foreign and anti-Chinese sentiment has been important (Mackie, 1988; Yoshihara, 1988; 1994; McVey, 1992). During the 1950s and 1960s, virtually all ASEAN countries were in their embryonic stage of industrialization. AntiChinese sentiment was rather deeply rooted in Indonesia and the Philippines (Robison, 1986; Mackie, 1988; Suryadinata, 1988; Yoshihara, 1994). In the Philippines, for example, the Chinese were seriously discriminated against under the Retail Trade Nationalisation Law enacted in 1954 since most small-scale Chinese businesses then were in retail and wholesale trade. In Thailand, the Chinese have been able to assimilate themselves into the Thai society while Sino-Thai businesses have experienced rapid growth under political and, often, military patronage (Suehiro, 1985; 1992; Mackie, 1988;

2 This paper excludes the former Indo-Chinese countries from its discussion of Southeast Asia.

3 This observation, of course, may not valid for the next few years because of the recent turmoil in Asian currency and stock markets. 
Table 1 Key macro-economic indicators for ASEAN countries, 1965-94

\begin{tabular}{|c|c|c|c|c|c|c|c|}
\hline Country & Year & $\begin{array}{r}\text { Real GDP } \\
\text { growth } \\
(\%)\end{array}$ & $\begin{array}{r}\text { GNP Per } \\
\text { Capita } \\
\text { (US\$) }\end{array}$ & $\begin{array}{r}\text { Inflation } \\
(\%)\end{array}$ & $\begin{array}{r}\text { Current } \\
\text { A/C BOP } \\
(\mathrm{US} \$ \mathrm{~b})\end{array}$ & $\begin{array}{r}\text { Gross } \\
\text { National } \\
\text { Savings } \\
(\% \text { GNP })\end{array}$ & $\begin{array}{r}\text { Gross } \\
\text { Capital } \\
\text { formation } \\
(\% \mathrm{GNP})\end{array}$ \\
\hline \multirow{8}{*}{ Brunei } & 1987 & 1.1 & 15.390 & 1.7 & 1.5 & - & - \\
\hline & 1988 & 2.2 & - & 2.0 & 1.4 & - & - \\
\hline & 1989 & 3.5 & 13,468 & 2.5 & 1.6 & - & - \\
\hline & 1990 & 3.0 & - & 2.5 & 1.8 & - & - \\
\hline & 1991 & 4.0 & - & 1.6 & 1.6 & - & - \\
\hline & 1992 & -1.1 & - & 1.3 & 1.5 & - & - \\
\hline & 1993 & -4.1 & 11,898 & 4.3 & 1.4 & - & - \\
\hline & 1994 & -2.0 & - & 4.5 & - & - & - \\
\hline \multirow[t]{11}{*}{ Indonesia } & $1965-85$ & 4.8 & 530 & - & - & - & - \\
\hline & 1985 & 2.5 & 500 & - & - & - & - \\
\hline & 1986 & 4.0 & 450 & - & - & - & - \\
\hline & 1987 & 4.9 & 450 & 9.3 & -2.1 & 32.5 & 32.8 \\
\hline & 1988 & 5.7 & 440 & 5.6 & -1.4 & 31.7 & 31.9 \\
\hline & 1989 & 7.4 & 500 & 6.1 & -1.1 & 35.3 & 36.5 \\
\hline & 1990 & 7.1 & 592 & 9.9 & -2.4 & 37.1 & 38.0 \\
\hline & 1991 & 6.9 & 638 & 9.4 & -4.1 & 35.4 & 37.3 \\
\hline & 1992 & 6.3 & 687 & 7.6 & -3.7 & 37.3 & 37.7 \\
\hline & 1993 & 6.5 & 763 & 9.2 & -2.0 & 38.0 & 37.3 \\
\hline & 1994 & 7.3 & 846 & 9.6 & -3.5 & 38.7 & - \\
\hline \multirow{11}{*}{ Malaysia } & $1965-85$ & 4.4 & - & - & - & - & - \\
\hline & 1985 & -1.0 & 2,000 & - & - & - & - \\
\hline & 1986 & 1.2 & 1,830 & - & - & - & - \\
\hline & 1987 & 5.4 & 1,814 & -0.8 & 2.7 & 33.6 & 24.5 \\
\hline & 1988 & 8.9 & 1,867 & 2.5 & 1.8 & 33.0 & 25.6 \\
\hline & 1989 & 8.8 & 2,040 & 2.8 & -0.2 & 30.0 & 31.5 \\
\hline & 1990 & 10.2 & 2,289 & 3.1 & -1.7 & 29.7 & 34.2 \\
\hline & 1991 & 8.7 & 2.589 & 4.4 & 04.2 & 28.4 & 37.4 \\
\hline & 1992 & 7.8 & 3,116 & 4.7 & -1.8 & 32.0 & 36.1 \\
\hline & 1993 & 8.3 & 3,338 & 3.6 & -2.5 & 32.7 & 36.8 \\
\hline & 1994 & 8.7 & 3,627 & 3.7 & -4.4 & 32.4 & 38.8 \\
\hline \multirow{11}{*}{ Philippines } & $1965-85$ & 2.3 & - & - & - & - & - \\
\hline & 1985 & -4.3 & 580 & - & - & - & - \\
\hline & 1986 & 1.4 & 560 & - & - & - & - \\
\hline & 1987 & 4.6 & 590 & 3.8 & -0.4 & 14.9 & 14.5 \\
\hline & 1988 & 6.4 & 630 & 8.8 & -0.4 & 18.0 & 18.5 \\
\hline & 1989 & 5.6 & 710 & 10.6 & -1.5 & 19.7 & 22.2 \\
\hline & 1990 & 2.5 & 760 & 12.7 & -2.7 & 16.2 & 21.6 \\
\hline & 1991 & -0.5 & 722 & 18.7 & -1.0 & 16.4 & 19.8 \\
\hline & 1992 & 0.1 & 825 & 8.9 & -1.0 & 14.7 & 20.4 \\
\hline & 1993 & 2.1 & 828 & 7.6 & -3.3 & 14.6 & 23.6 \\
\hline & 1994 & 4.3 & 937 & 9.3 & -3.2 & 15.0 & 23.9 \\
\hline \multirow[t]{11}{*}{ Singapore } & $1965-85$ & 7.6 & - & - & - & - & - \\
\hline & 1985 & -1.6 & 6,911 & - & - & 41.0 & 41.0 \\
\hline & 1986 & 1.8 & 6,766 & - & 0.3 & 38.6 & 36.9 \\
\hline & 1987 & 9.5 & 7,940 & 0.5 & 0.2 & 36.9 & 37.7 \\
\hline & 1988 & 11.1 & 9,070 & 1.5 & 1.3 & 41.0 & 33.5 \\
\hline & 1989 & 9.2 & 10,450 & 2.4 & 2.3 & 42.7 & 33.1 \\
\hline & 1990 & 8.3 & 12,433 & 3.4 & 2.4 & 43.9 & 35.5 \\
\hline & 1991 & 6.7 & 15,289 & 3.4 & 4.0 & 45.8 & 35.1 \\
\hline & 1992 & 6.0 & 17,208 & 2.3 & 3.8 & 48.1 & 35.9 \\
\hline & 1993 & 9.9 & 19,142 & 2.4 & 2.0 & 47.1 & 38.1 \\
\hline & 1994 & 10.0 & 19,740 & 4.7 & 2.5 & 49.8 & 32.3 \\
\hline
\end{tabular}


Table 1 Continued

\begin{tabular}{|c|c|c|c|c|c|c|c|}
\hline Country & Year & $\begin{array}{r}\text { Real GDP } \\
\text { growth } \\
(\%)\end{array}$ & $\begin{array}{r}\text { GNP Per } \\
\text { Capita } \\
\text { (US\$) }\end{array}$ & $\begin{array}{r}\text { Inflation } \\
(\%)\end{array}$ & $\begin{array}{r}\text { Current } \\
\text { A/C BOP } \\
\text { (US\$b) }\end{array}$ & $\begin{array}{r}\text { Gross } \\
\text { National } \\
\text { Savings } \\
(\% \text { GNP })\end{array}$ & $\begin{array}{r}\text { Gross } \\
\text { Capital } \\
\text { formation } \\
(\% \mathrm{GNP})\end{array}$ \\
\hline \multirow[t]{11}{*}{ Thailand } & $1965-85$ & 4.0 & - & - & - & - & - \\
\hline & 1985 & 3.5 & 810 & - & - & - & - \\
\hline & 1986 & 4.5 & 800 & - & - & - & - \\
\hline & 1987 & 9.5 & 850 & 2.5 & -0.3 & 23.6 & 24.0 \\
\hline & 1988 & 13.2 & 1,000 & 3.8 & -1.6 & 26.5 & 27.5 \\
\hline & 1989 & 12.0 & 1,220 & 5.4 & -2.4 & 28.3 & 31.4 \\
\hline & 1990 & 10.0 & 1,544 & 6.1 & -6.9 & 28.4 & 35.9 \\
\hline & 1991 & 8.1 & 1,726 & 5.7 & -7.7 & 32.2 & 41.9 \\
\hline & 1992 & 7.6 & 1,911 & 4.1 & -6.7 & 32.5 & 40.4 \\
\hline & 1993 & 8.1 & 2,124 & 3.3 & -6.9 & 34.2 & - \\
\hline & 1994 & 8.5 & 2,420 & 5.0 & -8.6 & 37.5 & - \\
\hline
\end{tabular}

Sources: Data for 1965-86 Guo (1993: Table 2); data for 1987-90 Ariff and Tan (1992: Table 1); data for 1991-94 Economist Intelligence Unit (1995); International Monetary Fund (1995).

Yoshihara, 1994). In Malaysia, the Chinese have experienced a more favourable political climate since the late 1980s (Jesudason, 1989; 1997).

The 1970s saw the emergence of major ethnic backlashes in Indonesia and Malaysia. The regulatory regimes became much more restrictive. Domestically, pressure was exerted to enable indigenous people, known as pribumi in Indonesia and bumiputra in Malaysia, to acquire a greater share of national economic wealth. In Malaysia, for example, the New Economic Policy (NEP) was launched in 1970 with two key objectives (Jesudason, 1989; 1997): to eradicate poverty in general and to achieve better ethnic economic parity. In order to achieve the latter objective, the Industrial Coordination Act of 1975 required all manufacturing establishments above a certain registered capital to be licensed under the Ministry of Trade and Industry. The initial minimum threshold for a shareholder's fund was $\mathrm{M} \$ 100,000$, but this was raised to $\mathrm{M} \$ 250,000$ in 1977 in an amendment to the act, and then recently increased further to $\mathrm{M} \$ 2.5$ million. It was hoped that by restricting both Chinese and foreign equity ownership, bumiputra ownership of the Malaysian corporate sector could eventually be increased from $2.6 \%$ in 1970 to $30 \%$ in 1990 .

From the 1980s onward, the attitudes of these ASEAN-4 countries changed toward more vigorous promotion of inward investments. The ethnicity issue has not disappeared completely but, instead, it is supplemented by an increasing influx of foreign capital. Ironically, a large proportion of this foreign capital originates from ethnic Chinese societies - for example Hong Kong, Taiwan and Singapore. Uneven development continues to be a prominent feature in the contemporary economic landscapes of many Southeast Asian countries (Jomo, 1988; Yoshihara, 1988; Jesudason, 1989; Kim et al., 1992). Recent riots in Indonesia demonstrate that the issue of ethnic inequality remains central to the stability and continued growth of many Southeast Asian countries. Ethnicbased economic policies aiming at improving the economic well-being of the pribumi in Indonesia and the bumiputra in Malaysia have effectively forced many ethnic Chinese business firms to reconsider their future growth strategies. Upon consolidating themselves in their domestic economies, many Chinese business firms in Southeast Asia begin to consider seriously diversifying their operations abroad in search of new investment opportunities that are unavailable or costly in their home countries as a result of state regulation. Well-known examples are the Salim Group from Indonesia, the Kuok brothers and the Hong Leong Group from Malaysia, the Charoen Pokphand (CP) Group and Bangkok Bank from Thailand and the Sy Group from the Philippines (Table 2; also East Asia Analytical Unit, 1995). In doing so, their strategies and processes of 
Table 2 National contexts of Chinese business firms from Southeast Asia

\begin{tabular}{|c|c|c|c|c|}
\hline Country & Growth and Market Potential & Presence of Chinese Business & $\begin{array}{l}\text { Policy towards Chinese Busi- } \\
\text { ness }\end{array}$ & Leading Ethnic Chinese TNCs \\
\hline Indonesia & $\begin{array}{l}\text { - high growth since } 1987 \\
\text { - weak domestic market } \\
\text { - many protected industries }\end{array}$ & $\begin{array}{l}- \text { small Chinese population ( } 5 \% \text { of } \\
\text { total) } \\
\bullet \text { long history of Chinese business } \\
\text { - presence in virtually all industries }\end{array}$ & $\begin{array}{l}\text { - ethnic-biased pribumi policy } \\
\text { - political patronage with Su- } \\
\text { harto }\end{array}$ & $\begin{array}{l}\text { - Salim Group controlled by Liem } \\
\text { Sioe Liong } \\
\text { - Lippo Group controlled by Mochtar } \\
\text { Riady }\end{array}$ \\
\hline Malaysia & $\begin{array}{l}\text { - high growth since } 1987 \\
\text { - emerging domestic market } \\
\text { - some protected industries }\end{array}$ & $\begin{array}{l}- \text { large Chinese population ( } 30 \% \\
\text { of total) } \\
\bullet \text { long history of Chinese business } \\
\text { - significant presence in property } \\
\text { and financial sectors }\end{array}$ & $\begin{array}{l}\text { - ethnic-biased bumiputra pol- } \\
\text { icy } \\
\text { - New Economic Policy since } \\
1969 \\
\text { • political patronage with Ma- } \\
\text { lays }\end{array}$ & $\begin{array}{l}\bullet \text { Kerry Group controlled by Robert } \\
\text { Kuok } \\
\bullet \text { Hong Leong Group controlled by } \\
\text { Quek Leng Chan }\end{array}$ \\
\hline Philippines & $\begin{array}{l}\text { - unstable growth since } 1985 \\
\text { - weak domestic market }\end{array}$ & $\begin{array}{l}\text { - small Chinese population }(\sim 1.5 \% \\
\text { of total) } \\
\text { - recent history of Chinese business } \\
\text { - limited presence in industries }\end{array}$ & $\begin{array}{l}\text { - ethnic-biased industrial policy } \\
\text { - political patronage with Mar- } \\
\text { cos }\end{array}$ & $\begin{array}{l}\text { - Fortune Tobacco controlled by Lu- } \\
\text { cio Tan }\end{array}$ \\
\hline Singapore & $\begin{array}{l}\text { - high growth since } 1987 \\
\text { - small domestic market } \\
\text { - large presence of foreign firms } \\
\text { and government-linked corpora- } \\
\text { tions }\end{array}$ & $\begin{array}{l}- \text { large Chinese population ( } 78 \% \\
\text { of total) } \\
\bullet \text { long history of Chinese business } \\
\text { - significant presence in commerce } \\
\text { and property sectors }\end{array}$ & $\begin{array}{l}\text { - no ethnic-biased policy } \\
\text { - strong role of the state and its } \\
\text { institutions }\end{array}$ & $\begin{array}{l}\text { - Hong Leong Group controlled by } \\
\text { Kwek Leng Beng } \\
\text { • Far East Organization controlled by } \\
\text { Ng Teng Fong }\end{array}$ \\
\hline Thailand & $\begin{array}{l}\text { - high growth since } 1987 \\
\text { - emerging domestic market } \\
\text { - some protected industries }\end{array}$ & $\begin{array}{l}\text { - significant Chinese population } \\
(\sim 14 \% \text { of total) } \\
\bullet \text { long history of Chinese business } \\
\text { - significant presence in commerce } \\
\text { and industries }\end{array}$ & $\begin{array}{l}\text { - ethnic assimilation policy } \\
\text { - political and military patron- } \\
\text { age }\end{array}$ & $\begin{array}{l}\text { - Charoen Pokphand Group controlled } \\
\text { by Chearavanont family } \\
\text { - Bangkok Bank controlled by So- } \\
\text { phonpanich family }\end{array}$ \\
\hline
\end{tabular}
of total)

- limited presence in industries

arge Chinese population ( $78 \%$

- long history of Chinese business

- significant presence in commerce

- long history of Chinese business

and industries ethnic-biased pribumi policy - political patronage with Su-

- controlled by Mochtar

- Hong Leong Group controlled by

- New Economic Policy since

- political patronage with Ma-

- ethnic-biased industrial policy - political patronage with Mar-

cio Tan

- no ethnic-biased policy

- strong role of the state and it enstitutions 
internationalization have also been shaped by the changing configurations of Chinese business practices in their 'home' countries.

\section{Reconfiguration of Chinese business systems}

It is important to view Chinese business firms as dynamic social institutions capable of constantly adapting to changing circumstances. Historically, the so-called 'spirit of Chinese capitalism' rests with their ability to network together to form a relatively coherent socio-economic group to survive discrimination in the host countries (Redding, 1990; 1995; 1996; Whitley 1992; Yeung, 1997b; 1998b). As Brown (1995: 9) notes, however, ' $[\mathrm{t}] \mathrm{he}$ importance of the Chinese networks still endures, but the complex changes they have undergone are crucial'. In Southeast Asia, significant changes in the Chinese business system have facilitated the cross-border operations of Chinese firms (see Lim, 1996; Yeung, 1999b). One of the foremost changes has been the softening of the power of the older generation (Greenhalgh, 1994; Whyte, 1996). Many features of the Chinese families in the past that appeared to hinder modern economic life have been altered, in particular, traits such as high fertility, extreme subjugation of women and the autocratic power of the senior generation. The softening of the power of the older generation implies that founders of family firms need to provide more incentives and autonomy for their grown children (most commonly, still their sons) within the firm in order to be successful, both as a firm and as a family. In this regard, the internationalization of domestic operations provides one of the best opportunities to train these upcoming younger successors and to unleash their entrepreneurial potential, albeit in a foreign setting.

Moreover, differences in Southeast Asian states contribute to spatial variations of the industrial configurations of Chinese business (Hamilton, 1996a). In Singapore, Chinese firms tend to engage in more western management practices because of their alliances with western TNCs and firms actively promoted by the state. The Local Industry Upgrading Program (LIUP) initiated by the Economic Development Board (EDB) of Singapore, for example, facilitates collaborative ventures between local Chinese SMEs and their TNC counterparts. In other Southeast Asian countries, Chinese business firms are able to identify the initiatives of nation states and pool capital and appropriate technology, e.g. in the privatization of major public sector industries in Indonesia, Malaysia and Thailand during the 1980s and 1990s. In order to secure privileged access to these governmentrelated opportunities, many Chinese firms are engaged in patron-client relationships with leading political and military leaders. As shown in Table 2, an unintended consequence of this quest for privileged access to government contracts is the narrow focus of large Chinese business conglomerates in Southeast Asia on commercial and trading activities as well as infrastructural development, rather than export-oriented manufacturing which is the platform of globalization for many leading global corporations. The former industries offer much faster return to investment than manufacturing industries. Increasingly these Chinese business firms also come together to form regional consortiums in order to pool resources to compete with foreign capital. Hamilton (1996b: 337) observes that 'Chinese capitalism is not confined to a political space the way many other forms of capitalism have been. Rather, Chinese capitalism fills an economic space'. They play a major economic role in the internationalization of business activities from Southeast Asia.

\section{The internationalization of Chinese business firms from Southeast Asia}

These changes in the global context of competition and the local configurations of Chinese business systems provide favourable conditions for the internationalization of ethnic Chinese business firms from Southeast Asia. This section aims to examine their 
strategies of internationalization and modes of transnational operations. The discussion draws on several case studies of leading Chinese business conglomerates from Southeast Asia. Table 3 summarizes their operating contexts and strategies of internationalization.

\section{Strategies of internationalization}

As highlighted in the introduction, one strategy commonly adopted by Chinese conglomerates from Southeast Asia in their internationalization process is sectoral specialization through forward and backward integration. This strategy is applicable to both manufacturing and non-manufacturing Chinese firms when specialization takes place in different segments of production chains. For manufacturing firms, sectoral specialization refers to focusing on certain core manufacturing capabilities to achieve scale economies and cost advantages (see Porter, 1985). For non-manufacturing firms (e.g. finance and property development firms), sectoral specialization often means continuous expansion of the corporate group to establish a significant presence in different markets. Market access becomes a key concern to these firms. In this regard, transnational operations have become a means through which these conglomerates consolidate their competitive position in particular business fields and extend their valueadded activities in production chains. For example, the production chain in agribusiness includes a broad range of agricultural, forestry and marine products and the processes' products. Koike (1993: 368) notes that 'agribusiness is attracting renewed interest as a highly promising field, although for it to further develop, the region's agricultural infrastructure needs to be drastically improved. Ethnic Chinese business groups in Southeast Asia will continue moving into agribusiness for some time to come, particularly in view of the potential of the mainland Chinese market'.

One of the best examples of a Chinese conglomerate specializing in agribusiness is the Charoen Pokphand (CP) Group from Thailand (see Table 3). Today, it may be the single largest investor in China. The Group was founded some 70 years ago by two ethnic Chinese brothers, Chia Ek Chor and Chia Seow Whooey, who arrived in Thailand in 1919 from the Shantou region of Guangdong (East Asia Analytical Unit, 1995: 323-6; Hamilton and Waters, 1995: 104-5; Weidenbaum and Hughes, 1996: 30-4). The CP Group started in the farm-seed business and moved into animal feeds and then into chicken farming and processing with initial technical support from the US poultry giant, Arbor Acres. As explained by its Executive Vice President, Dr Veerawat Kanchanadul:

CP executives have realised the globalisation trend even 20-25 years ago, not just now. Moreover, we also started to realise our capability to absorb new technological skills from our joint venture partner and to apply those skills to developing countries. That was the reason why we diversified into industries other than agriculture. We realised that the growth in agricultural sectors was slowing down. No matter how big you are, if you operate in a declining industry, you won't grow (Quoted in Pananond and Zeithaml, 1997: 21).

Although the Group's interests extend to petrochemicals, motorcycle and automotive parts, real estate and telecommunications, 60-70\% of its revenue is still derived from agribusiness. During the 1980s, the CP Group became Asia's biggest exporter of processed and frozen chickens, mainly to Japan, China and Brazil. In all, the CP Group now controls more than 280 affiliated companies, of which only 14 are listed on stock exchanges worldwide (see Table 4). In 1993, the Group officially reported US\$5 billion in revenues. In 1995, the Chearavanont family's wealth was estimated at US\$5.5 billion, placing it as the 25th wealthiest in the world (Shikatani, 1995: Table 1). To tap into China's huge domestic market, the CP Group set up its first China venture, Conti Chia Tai, in Shenzhen in 1981, and was an early entrant into the China market. It now has operations in 26 of China's 30 provinces, indicating its broad interests in China and desire for greater geographic coverage. The Group's total assets in China were estimated at US\$1.3 billion in 1993 (East Asia Analytical Unit, 1995: 324; Brown, 1998). Its China 
Table 3 Operating contexts and internationalization strategies of selected Chinese business firms from Southeast Asia

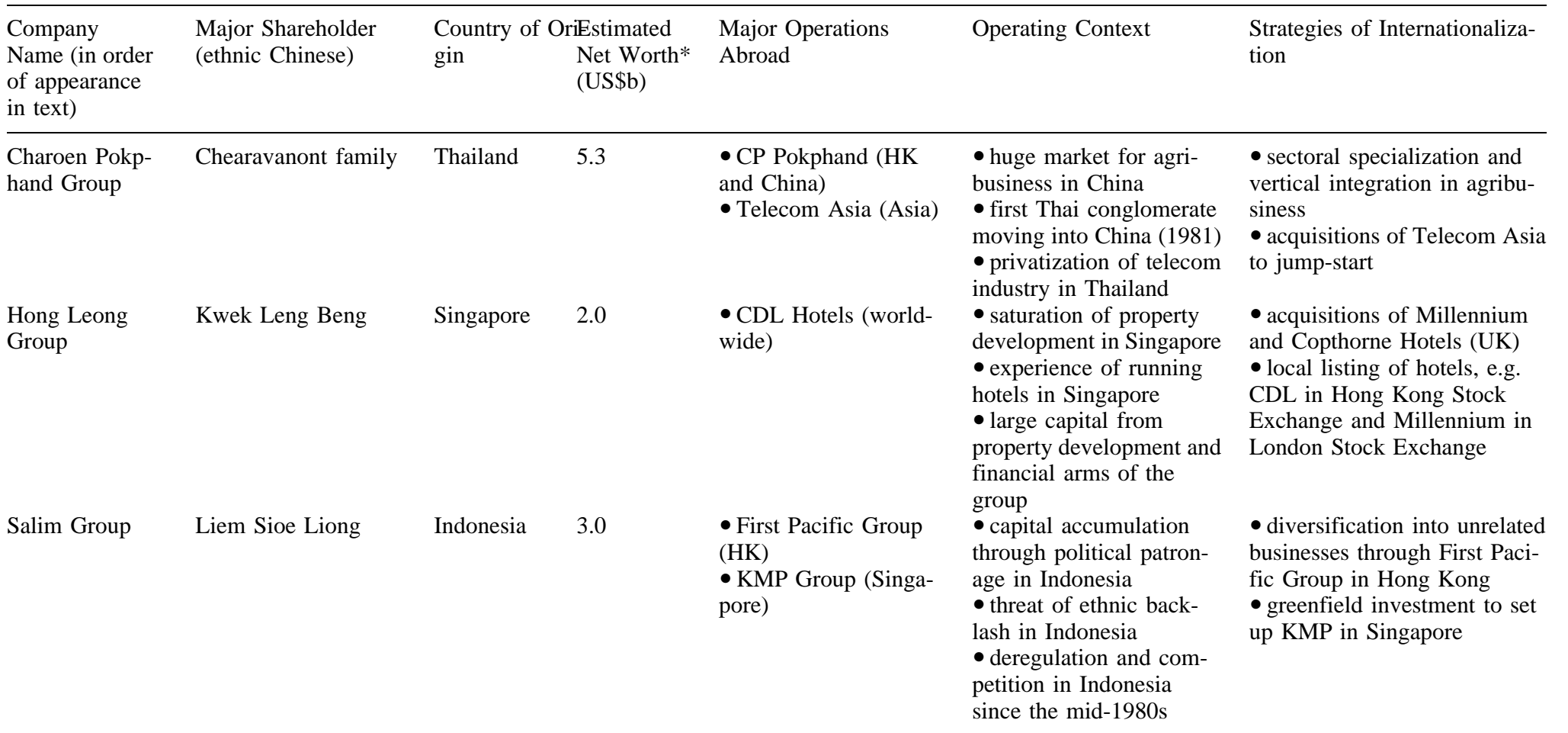

* East Asia Analytical Unit (1995: Table 6.1). 
Table 4 Listed members of the Charoen Pokphand Group

\begin{tabular}{llrrr}
\hline Name of Company & Stock Exchange & $\begin{array}{r}\text { Market } \\
\text { Capitalization in } \\
\text { November 1994 } \\
\text { (US\$million) }\end{array}$ & $\begin{array}{r}\text { Net Profit } \\
\text { in 1993 }\end{array}$ & $\begin{array}{r}\text { CP Stake } \\
\text { (percentage) }\end{array}$ \\
\hline EK Chor China Motorcycle & New York & 360 & 20 & 72 \\
CP Pokphand & Hong Kong, London & 622 & 44 & 56 \\
Hong Kong Fortune & Hong Kong & 107 & 0 & 64 \\
Orient Telecom \& Technology & Hong Kong & 896 & 12 & 51 \\
CP Indonesia & Jakarta & 234 & 13 & 71 \\
CP Prima & Jakarta & 198 & 6 & 92 \\
CP Enterprise & Taipei & 132 & 2 & 30 \\
Shanghai Dajiang & Shanghai & 141 & 17 & 44 \\
CP Feedmill & Bangkok & 839 & 48 & 39 \\
CP Northeastern & Bangkok & 60 & 3 & 59 \\
Bangkok Produce Merchandising & Bangkok & 49 & 3 & 37 \\
Bangkok Agri-Industrial Products & Bangkok & 118 & 4 & 73 \\
Telecom Asia & Bangkok & 9,030 & 23 & 29 \\
Siam Makro & Bangkok & 875 & 6 & 15 \\
\hline
\end{tabular}

Source: East Asia Analytical Unit (1995: Table A7.1).

investments are mainly conducted through its Hong Kong subsidiary, CP Pokphand, which controlled 36 very diversified businesses in China in 1993.

Another example of horizontal integration is the internationalization of the Singapore branch of the Hong Leong Group into the hotel business through its property development arm - City Development Ltd (CDL) (see Table 3). The Hong Leong Group is one of the largest Chinese business groups in Singapore with a market capitalization of US\$16 billion and employs 30,000 worldwide (The Sunday Times, 2 February 1997). The founder of the Hong Leong Group was the late Kwek Hong Png, who came to Singapore from Fujian, China in 1928. Over a period of half a century, he managed to build up a vast business empire, starting with trading, then expanding into property, finance and hotels. CDL Hotels International, listed in the Hong Kong Stock Exchange, constitutes the group's main hotel interest. Since the late 1980s, CDL Hotels International has grown tremendously from owning only six hotels in 1989 to 62 in 1997. CDL Hotels International now has a hotel empire spanning 13 countries in Europe, the US, Australia, New Zealand, East and Southeast Asia. It is now the eighth largest hotel owner and operator in the world (The Straits Times, 29 October 1997). Its success in acquiring hotels on a global scale rests not only with the excellent business acumen of its present chairman, Kwek Leng Beng (son of the late Kwek Hong Png), but also with the sheer financial muscle of the Hong Leong Group. The Group is a major property developer and finance house in Singapore.

A second key internationalization strategy of ethnic Chinese business firms from Southeast Asia is diversification into unrelated businesses (e.g. the Salim Group from Indonesia and the CP Group from Thailand). At least two reasons explain why diversification has been preferred by these Chinese business firms. First, many Chinese business firms gain their fame through investments in real estate and trading businesses (e.g. Robert Kuok from Malaysia). They have subsequently become cash-rich and need to reduce their risks because of over-reliance on returns to investments in these two volatile sectors. Diversification into other business fields offer attractive alternatives to hedge their risks. Another reason for risk diversification has been the pervasive threat of host government expropriation and ethnic discrimination. Second, diversification into different business activities is most preferred by Chinese business firms because of their 
diverse networks involving personal and business relationships. When a leading Chinese business person is approached by a friend or business associate from another industry for equity investment, an agreement may be struck to promote friendship and relationship (guanxi) even though there may be no complementarity between their businesses. As a result, the diversification of Chinese business firms into different business fields is often determined by social relationships, not by strategic necessity. As observed by Koike (1993: 371), 'the group aggressively seizes numerous large and small business opportunities as they randomly arise, and systematically, or even unsystematically, adds to its operations new business lines one after another'. For example, although the diversification of Thailand's CP Group from feed mills to poultry farming is rather predictable, it is much more difficult to rationalize why it has diversified into and become successful in motorcycle manufacturing and telecommunications joint ventures (Weidenbaum and Hughes, 1996; see also Table 4). One of its largest ventures outside its agribusiness core is its stake in TelecomAsia, a joint venture with the US telecommunications giant NYNEX.

The internationalization of the Salim Group has also been closely linked to ongoing expansion and diversification of its domestic operations in Indonesia (see Table 3). Sato (1993) has identified several phases in the development of the Salim Group. Founded in 1953, Liem Sioe Liong's group of companies focused on trading in important commodities. From the late 1960s to the mid-1980s, the Suharto government pursued import-substitution policies and promoted such industries. Liem was one of the main beneficiaries of this policy. The group's total capital during the 15 years from 1970 grew at an average annual rate of 46\%. By 1985, it had reached US $\$ 550$ million, a 300-fold increase since 1970 (Sato, 1993: 413). This process of rapid expansion and diversification can be divided into four major phases: (1) entry into manufacturing (1968-74); (2) setting up banking (1975-78); (3) expanding the cement business (1977-81); and (4) conglomerate diversification into unrelated businesses (1981-85). During the first phase (1968-74), the Salim Group focused on developing domestic manufacturing operations in Indonesia (e.g. textiles, flour milling and automobile assembly). However, it was only during the second phase (1975-78) that the Salim Group made its first serious inroads into overseas operations. Established in 1957, Bank Central Asia (BCA) underwent significant restructuring during this period under the management of Mochtar Riady, who was appointed its president in May 1975. In order to compete with other domestic private banks in Indonesia by raising low-cost funds needed for relatively low interest-rate lending, Liem and Mochtar jointly set up a deposit taking company, the Central Asia Capital Corporation in Hong Kong in May 1975 (Sato, 1993: 416).

The Salim Group established another significant presence in Hong Kong during the fourth phase (1981-85), when it acquired the First Pacific Group in 1981. Establishing subsidiaries in Hong Kong (and later in Singapore) has enabled the Salim Group to take advantage of lower taxation, to hedge against business risks, to facilitate financial operations and information collection and, perhaps most importantly, to disguise real ownership of assets by the group in anticipation of negative public sentiments in home countries. Until recently, the First Pacific Group was synonymous with the Salim Group's overseas operations. Its four main lines of business have been: the distribution and sale of consumer goods; finance and banking; real estate and property; and telecommunications. Through First Pacific, the Salim Group successfully acquired the long-established Dutch trading company Hagemeyer NV, the Thai trading company Berli Jucker Co Ltd and Metro Drugs Inc of the Philippines. Hagemeyer had an extensive network of overseas operations spanning at least 21 countries in Europe and Asia.

The recession of the mid-1980s in Indonesia resulted in fundamental structural changes in the Indonesian economy and the policy shift in 1983 from import-substitution to export-oriented industrialization (Robison, 1986). The policy of protection and subsidies for domestic industries was gradually replaced by deregulation and competition. 
The Salim Group responded to this changing national context by liquidating the debt burden of its import substitution industries (e.g. cement and steel businesses) using its 'political-economic alliance' to the maximum and shifting investments to promising new industries (e.g. agribusiness, oleochemicals, labour-intensive manufacturing, industrial estates and tourism) (Sato, 1993). A consequence of this domestic restructuring of the Salim Group was that from around 1988, the businesses connected with various domestic enterprises began to expand their operations overseas from Singapore. The Group's umbrella company in Singapore has been KMP Pte Ltd, first established in Singapore in 1983. As seen in Table 5, the KMP Group has become much more active since 1990 and acquired a leading local industrial conglomerate, United Industrial Corporation Ltd. (UIC), in 1990 (Sato, 1993: 425). The purpose of establishing and acquiring these companies was to facilitate the vertical integration of the production chains of domestic operations in Indonesia.

A third internationalization strategy pursued by Chinese business firms from Southeast Asia is family ownership and management to exercise strict control and intragroup coordination among foreign affiliates. One explanation is that these Chinese business firms are still relatively inexperienced in internationalization. Internalization of management and control therefore provides a better safety net for these firms to protect their firm-specific advantages and to maximize their benefits from network relationships with other firms abroad. Typically, a Chinese firm from Southeast Asia prefers centralization through family ownership and control. The ownership structure often develops into very intricate intra-group shareholdings which reflect the patriarch's desire to keep the whole group under control with minimum investment of their own and maximum mobilization of external resources. For example, the Salim Group carried out a group-wide organizational rationalization between 1985 and 1987 (Koike, 1993; Sato, 1993). Figure 1 shows that at the top of this new management organization is a board of directors for the group as a whole overseeing several different divisions. Each division has a division steering committee that decides basic division policy and a division management committee which supervises division management. Below each division are sub-divisions composed of individual affiliated firms at the bottom of this hierarchical structure of Salim Group management. At the moment, the board of directors at the top of the Salim Group is chaired by the founder, Liem Sioe Liong, himself. His second son is vice-chairman, and third son president and CEO. The executive directors and other key executives are all professional managers. One of the main reasons for this centralization of ownership and management within the Salim Group is the promotion of cross-border production chains (Sato, 1993). As the Group's domestic and transnational operations are increasingly integrated vertically, a unified management is necessary. Instead of forming a separate international division, the overseas operations of the Group are horizontally integrated into the 11 divisions according to the nature of business (see Figure 1).

In other Southeast Asian countries, the extent of family control and ownership among Chinese business firms is also significant. In his study of the characteristic features of top management levels in large-scale Thai-owned corporations in 1988, Suehiro (1993: 392) found that $60 \%$ of the company presidents and $63 \%$ of the board chairs are members of the top stockholding families. Where the top stockholding family controls over $50 \%$ of the stock, it is almost certain that a family member will be appointed to at least one CEO position. Most large Thai-owned corporations are therefore of the ownership/familycontrol type rather than management-control type. Table 6 shows the ownership structure of the CP Group around 1983. Chia family members controlled virtually all 20 affiliates. In another study of the top 250 manufacturing firms in the Philippines in 1970, Yoshihara (1985) found that among ethnic Chinese-controlled firms, 85\% were family-owned and managed. Palanca (1995: 198) also notes that '[d]espite the exposure of the younger generation to modern types of business and the increase in connections with the other elite groups of society, the modern Chinese still preferred to keep their core business links

(C) Joint Editors and Blackwell Publishers Ltd 1999 
Table 5 Major affiliates under Salim's KMP Group in Singapore

\begin{tabular}{llll}
\hline Company Name & $\begin{array}{l}\text { Set Up/ } \\
\text { Acquired }\end{array}$ & Type of Business & Newly Set up/Acquisition/Capital Participation (CP) \\
\hline KMP Pte Ltd & 1983 & Holding company of the KMP Group & Newly set up \\
Singapore Indusco Holdings Pte Ltd & 1967 & Investment company & Unknown \\
KMP Investments Pte Ltd & 1983 & Import-export and investment company & Newly set up \\
KMP Properties Pte Ltd & 1983 & Holding company & Newly set up \\
KMP Credit Pte Ltd & 1983 & Money lending and agencies & Newly set up \\
Sinpac Investment Pte Ltd & 1989 & Investment company & Newly set up \\
KMP-Hai Sun Hup Shipping Pte Ltd & 1990 & Barge, tugboat and sampan services & Newly set up \\
KMP Coastal Oil Pte Ltd & 1990 & Warehousing and petroleum products & Acquisition of Gold Coin Singapore Pte Ltd \\
KMP Feedmills Pte Ltd & 1990 & Manufacture of animal feeds & Acquisition of Lamipak Pte Ltd \\
Lamnipak KMP Pte Ltd & 1990 & Manufacture of plastics and household wares & Acquisition of Abalon Bay Pte Ltd \\
KMP Food Industries Pte Ltd & 1990 & Production/processing of meat and poultry & CP \\
Inno-Pacific Holdings Ltd & 1990 & Franchise holder of Kentucky Fried Chicken & CP \\
Shakey's Holdings Pte Ltd & 1990 & Franchise holder of Shakey's Pizza & Acquisition of shares hold by Oei Hong Leong, \\
United Industrial Corporation Ltd & 1990 & Holding company of the UIC Group & largest shareholder \\
& & &
\end{tabular}

Source: Sato (1993: Table VI). 


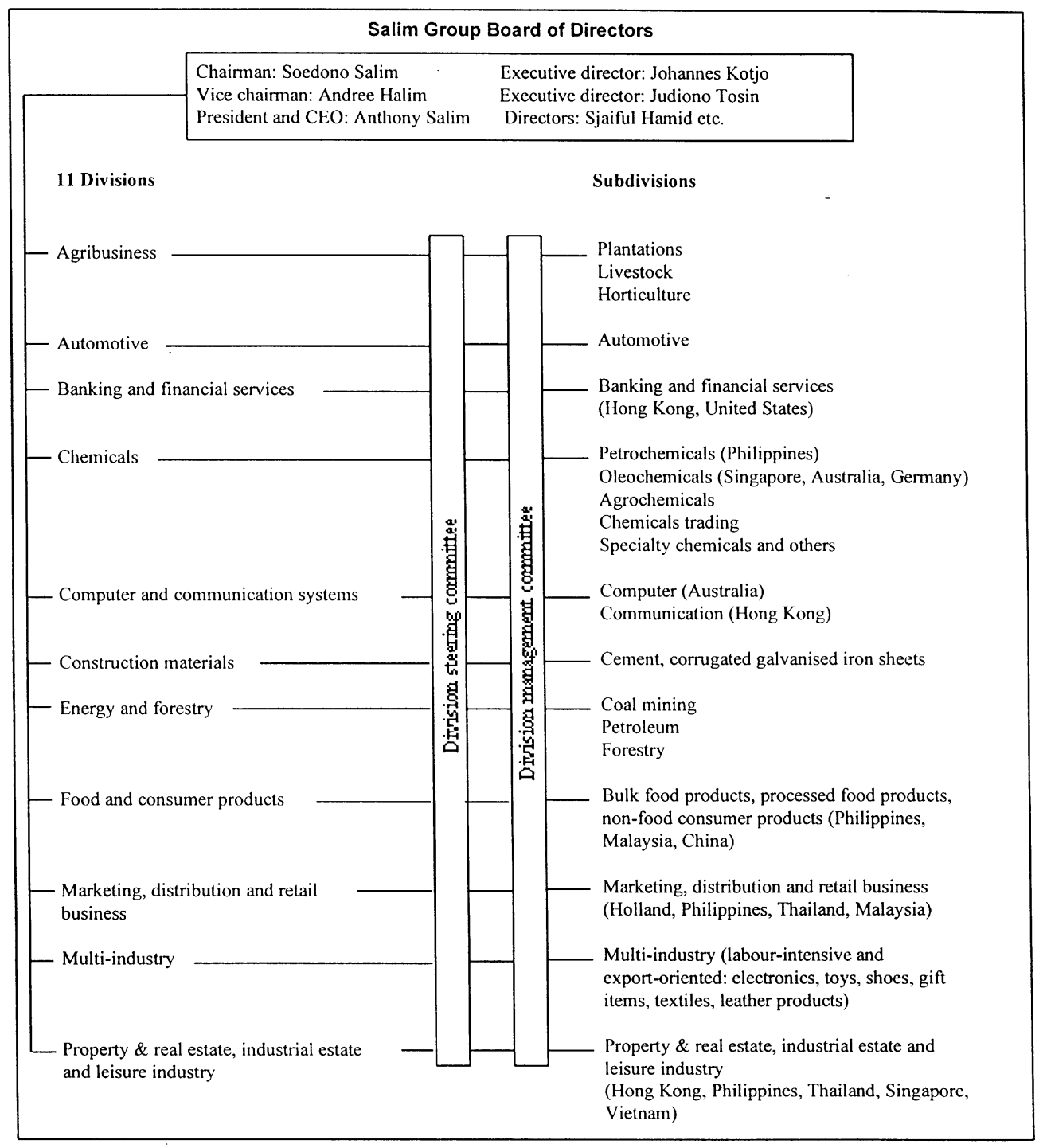

Figure 1 The Salim Group's new management system, 1991 (source: Sato, 1993: Figure 2)

within the family. Although there are partnerships with Filipino and foreign counterparts, the control remained within the family'.

\section{Modes of entry}

The internationalization of Chinese business firms takes a great variety of organizational forms. The choice of different modes of entry into foreign markets becomes an important issue in understanding their internationalization processes. In general, there are many ways of organizing transnational operations, from arm's-length market transactions (i.e. exports) to fully-integrated vertical hierarchies (i.e. FDI). Joint ventures and acquisitions are perhaps the most common organizational modes through which Chinese business firms internationalize their operations. In fact, many Chinese business firms in China are joining hands with local enterprises and state institutions (e.g. the CP Group above). 
Table 6 Ownership structure of CP Group, 1983

\begin{tabular}{|c|c|c|c|c|c|}
\hline Company Name & $\begin{array}{l}\text { Year of } \\
\text { Establishment }\end{array}$ & Type of Business & $\begin{array}{l}\text { Family } \\
\text { Members }^{\mathrm{a}}\end{array}$ & $\begin{array}{c}\text { Stockholding }(\%) \\
\text { Investment } \\
\text { Companies }\end{array}$ & $\begin{array}{c}\text { Group } \\
\text { Companies }^{c}\end{array}$ \\
\hline 1. Chia Tai Seeds \& Agricultural & 1951 & Fertiliser importing & 100 & - & - \\
\hline 2. Charoen Pokphand Feedmill & 1967 & Feed milling & 61 & 27 & - \\
\hline 3. Charoen Pokphand Produce & 1967 & Broiler raising & 82 & 12 & - \\
\hline 4. Bangkok Feedmill & 1968 & Feed milling & 64 & 11 & - \\
\hline 5. Kasetphan Industry & 1970 & Chicken farming & 36 & 12 & 7 \\
\hline 6. Arbor Acres (Thailand) & 1971 & Parent stocks & - & - & 50 \\
\hline 7. Advance Pharma & 1971 & Vaccine importing & 70 & 10 & - \\
\hline 8. CP Textile & 1973 & Textiles & 17 & 50 & - \\
\hline 9. Bangkok Farm & 1973 & Chicken breeding & 56 & 23 & - \\
\hline 10. Bangkok Livestock Processing & 1973 & Broiler processing & 58 & 23 & - \\
\hline 11. Bangkok Fisheries & 1974 & Fish-ball processing & 50 & - & 50 \\
\hline 12. J.P. \& Sons & 1975 & Investments & 75 & - & - \\
\hline 13. Montri \& Sons & 1975 & Investments & 100 & - & - \\
\hline 14. Bangkok Im-Ex & 1976 & Agricultural exporting & - & 16 & 56 \\
\hline 15. Charoen Pokphand Investment & 1976 & Investments & 10 & - & 54 \\
\hline 16. Bangkok Food Product & 1977 & Food processing & 68 & - & 23 \\
\hline 17. CP Feedmill & 1977 & Food milling & 68 & - & 23 \\
\hline 18. Sumeth Investment & 1978 & Investments & - & 100 & - \\
\hline 19. CP intertrade & 1979 & General trading & - & 28 & 36 \\
\hline 20. Bangkok Produce Merchandising & 1979 & Agricultural exporting & 57 & 23 & 11 \\
\hline
\end{tabular}

${ }^{a}$ Combined percentage of Chiarawanon family members.

${ }^{\mathrm{b}}$ Family-owned investment companies (Companies 12, 13, 15 and 18).

c Companies 2, 4 and 10.

Source: Suehiro (1993: Table IV). 
Acquisitions are also preferred by large Chinese business conglomerates to control their foreign subsidiaries (e.g. the Salim Group above). Other cooperative strategies in internationalization, such as informal networks and strategic alliances, are also adopted by Chinese business firms from Southeast Asia. These cooperative strategies are socially embedded in ongoing personal and business relationships among Chinese, and sometimes non-Chinese, business people (see Yeung, 1997b).

What, then, explains the choice of organizational modes in the internationalization of these Chinese business firms? Two sets of explanations are relevant: (1) institutional contexts and (2) firm-specific advantages. In their domestic institutional contexts, many Chinese family firms from Southeast Asian countries face discrimination in their home countries. Many decide to operate outside their home countries in order to transcend such home country limits to growth. As a result, foreign-based affiliates are used to offset accusations of capital flight. For example, the Salim Group diversified its capital assets outside Indonesia not through direct acquisitions, but rather through its Hong Kong-based First Pacific Group (Weidenbaum and Hughes, 1996). Acquisitions, rather than greenfield operations, are preferred because of speed and risk factors.

Another component of the institutional context is the host country business environment. When Chinese business firms from Asia try to venture into unfamiliar markets in North America and western Europe, acquisitions are preferred because the open business environment does not give these Chinese business firms any competitive advantage which they previously enjoyed in the more opaque Asian business environments. Rather, these open business fields in the West (e.g. high-tech industries) tend to experience intensified competition which accentuates the importance of economies of scale and technological innovations, particularly to those new entrants from Asia. Acquisitions of existing operations in these countries facilitate risk minimization, experience-building and major subsequent investments in the host countries. On the other hand, the more opaque business environments in China and most Southeast Asian countries favour joint ventures between Chinese business firms and indigenous enterprises/state institutions. These Chinese business firms may also team up with western firms in order to establish themselves in some Asian countries. Chinese business firms from Singapore have long been promoting themselves as the 'gateway' to the East for the West. For example, in May 1994, Keppel (a government-linked corporation) led a consortium of 19 Singapore companies to form the Singapore-Suzhou Township Development Company (SSTDC) to develop the Suzhou Industrial Park in China. The Suzhou project aims to produce an industrial park modelled after Singapore in order to attract investment by foreign TNCs (Yeung, 1998a).

Firm-specific advantages also play an important role in explaining the choice of internationalization mode by Chinese business firms. If a particular firm's key internationalization strategy is to secure technology and market share in order to overcome its lack of such firm-specific competitive advantages, it may choose to acquire directly existing foreign operations. This approach is particularly favoured by Singaporean electronics firms when they expand into the US market (e.g. acquisition of Silicon Valley electronics firms by Singapore Technologies). When a Chinese business firm has gained sufficient firm-specific competitive advantages in its domestic countries (e.g. through political-economic alliance with dominant elite or monopolistic practices), it may pursue a beach-head strategy for internationalization. In this case, the firm may first engage in joint ventures with foreign firms to 'test the water'. The foreign joint venture operation also serves as a marketing and information gathering intelligence unit to prepare the parent firm for the eventual establishment of wholly-owned subsidiaries in the host countries. For example in Singapore, the state-owned Singapore Technologies formed a joint venture with Sierra Semiconductor Corp of San Jose to manufacture wafers for integrated circuits. They also took a major stake in Momenta Corp in Mountain View to make pen-based computers (Hu, 1995: 85). 
A Chinese business firm may also prefer acquisition over other forms of transnational operations in order to gain economies of scale quickly. Once critical mass is achieved in a particular host country, the firm can exploit its business networks and other cooperative strategies to further its growth. For example, after acquiring Berli Jucker in Thailand and Metro Drugs in the Philippines, the First Pacific Group based in Hong Kong (the acquisition arm of the Salim Group) has enjoyed rapid growth through a sizeable presence in both host countries. Its operations in Malaysia, however, are small in scale and do not allow economies of network synergy. As explained by its Group Financial Controller, Stephen Young,

I think what's been more successful for us is where we have managed to build up a sizeable business in a country. Thailand and the Philippines will be good examples. Because if you can have a sizeable presence, then this networking, which you are talking of, seems to be relatively successful because you have your own critical mass in that country. So for us, Thailand and the Philippines are good examples. The other example we have is in Malaysia where we tried to build a large business group by putting together a series of small businesses. But that wasn't particularly successful and we have found trying to operate through small business doesn't work because you don't have connections, you don't have the influence that you could have through operating a sizeable business (author's interview, 13 March 1994).

Acquisition of existing affiliates abroad, as a form of direct investment, often enables Chinese business firms from Southeast Asia to engage in transnational operations and expand into new markets and production sites. In order to sustain this process of internationalization, these Chinese business firms rely on both existing competitive advantages derived from their home countries and new sources of advantages developed in the host countries.

\section{The competitive advantage of Chinese business firms from Southeast Asia}

An important question concerns the global competitiveness of ethnic Chinese business firms from Southeast Asia and the international transferability of their competitive advantage derived from their embeddedness in 'home' country institutions. This section proposes that the competitive advantage of Chinese business firms from Southeast Asia is embedded in their capabilities in network formation and exploitation. These capabilities, in turn, are both culturally and economically determined. Culturally, Chinese business traditionally relies on business networks to facilitate transactions and circumvent host country discrimination. Weidenbaum and Hughes (1996: 59) note that as a group, the overseas Chinese family firms have become the pacing element in the economies of Southeast Asia, and they are likely to continue in that role. Western firms will be forced in the years ahead to learn far more about the culture underlying the conduct of the bamboo network enterprises that may eventually become their competitors or partners or both'. This networking capability historically underscores the competitiveness of Chinese business firms vis-à-vis western firms in China. As observed by Hamilton (1996a: 18), '[a]mong Chinese businesspeople, competition and guanxi organization go hand-in-hand, and I believe this is the reason that Westerners, with their corporate forms of organization that separate one firm from another, one entrepreneur from another, have historically been unable to compete head-to-head with the Chinese'.

The cultural explanation of the so-called 'Overseas Chinese' success (e.g. Redding, 1990; Hamilton, 1991) has recently been questioned because of its inherent methodological pitfalls in terms of parochialism, exclusive focus on Chinese business and lack of comparative analysis of familism in other ethnic groups (Greenhalgh, 1994; Braadbaart, 1995; Hodder, 1996; Dirlik, 1997). It is equally important to examine the economic 
tendencies of Chinese business firms. Economically, Chinese business firms tend to engage in industries and/or sectors which promise quick return to investment (e.g. retail and wholesale, property development and finance and so on). Cultures per se, therefore, do not explain the success or failure of particular communities or forms of organizations. It is rather a combination of cultural traditions and economic practices within the broader context of global changes that explains the outcome of economic competition. Blim (1996: 87 ) thus argues that '[i]t is within organizations and structures of livelihood, capital and power that cultures abound'. The following penultimate section examines several sources of the competitive advantage of Chinese business firms in their transnational drive.

It is often argued that Chinese business firms in Southeast Asia engage in politicaleconomic alliances in order to obtain privileged access to markets and resources. When these firms internationalize their operations, such political-economic alliances will not provide a significant source of competitive advantage except that they enable these Chinese business firms to build up sufficient capital and market bases in their home countries, thereby enabling cross-border acquisitions. In the case of the Salim Group, its rapid expansion and diversification in the past three decades is, to a certain extent, facilitated by the personal patronage of former President Suharto. Because of his close relationship to Suharto, Liem was able to obtain monopoly rights in many newly established industries which were protected under the import-substitution industrialization policy in Indonesia (e.g. cement and flour milling). He then used the monopoly rents generated by these protected ventures to acquire major commercial and industrial affiliates in Hong Kong and Singapore. In this sense, the political-economic alliances in their home countries are important in preparing Chinese business firms to take over foreign operations at later stages.

In Singapore, the political-economic alliances are formed between major local enterprises and the state (see Rodan, 1989; Yeung, 1999c). The state not only drives the regionalization process through its government-linked corporations (e.g. Temasek Holdings and Singapore Technologies) and their transnational activities, but also offers various incentive schemes (through the Economic Development Board) to assist domestic firms in capturing regional and global markets (Yeung, 1998a). By 1993, there were over 60 such schemes and programmes addressing a broad spectrum of business needs. The state's target is to nurture 100 such SMEs into major players in the regional economy. The corporatist state has thus been partially transformed into an 'entrepreneurial state'. The idea is to develop Singapore into a global city with significant networking capabilities so that Singapore can be not only an attractive manufacturing investment location for global TNCs, but also an ideal springboard for these TNCs to expand into the Asian Pacific region .

Apart from the political-economic alliances, Chinese business firms in Southeast Asia also gain competitive advantage from the formation of personal and business networks. These networks have proved to be a significant source of competitive advantage when these firms compete with foreign firms in regional and global markets. Hamilton (1996a: 17), for example, argues that ' $[\mathrm{t}]$ hese guanxi networks, therefore, add scope and depth to the family firm. By being part of such guanxi networks, family firms are tied to other family firms so that, by combining, they reach beyond the limitation imposed by their size, both geographically and economically'. First, Chinese business networks facilitate access to capital. Brown (1995: 14) observes that:

At first the families were the major shareholders, then holding companies were established to control associated firms as well as the bank. At this point, investment and finance companies worldwide were incorporated as joint partners, between the family and other investors. Finally, the core bank, together with the other investment companies, became an important supplier of capital for existing or newly associated companies. This formidable combination of financial and corporate units was able, through interlocking stock ownership and interlocking directorates, to mount an aggressive expansion into the Pacific Rim, and into North America 
and Europe. As a result, it was not only able to draw funds into South East Asia but also out of the region and into USA, China and elsewhere.

For example, Mochtar Riady, the founder of Lippo Bank which operates in the Triad regions, was invited by Liem Sioe Liong to head the Bank of Central Asia (BCA) in May 1975. Liem offered Mochtar $17.5 \%$ of all BCA shares and entrusted him with directing the BCA for the next 15 years. Prior to his appointment at BCA, Mochtar had carried out the restructuring of two other banks and was president of the Panin Bank, then Indonesia's pre-eminent private bank (Sato, 1993). His BCA stint enabled him to establish very congenial relations with Liem, who later helped him financially to build up his Lippo empire.

Second, market knowledge, economic synergy and high degrees of operational flexibility can also be achieved through business networks. Weidenbaum and Hughes (1996: 53) argue that:

[T]ransnational trading networks are very much in accord with Chinese tradition. They allow for the flexible and efficient transmission of information, finance, goods and capital in what are often informal agreements and transactions. Confidence and trust replace contracts as the major guarantees that commitments will be met satisfactorily. In a region where capital markets are rudimentary, financial disclosure is limited, and contract law very weak, interpersonal networks are critical to moving economic resources across political boundaries.

The example of the CP Group and their operations in China shows that their growing competencies in previously unrelated businesses and strong joint venture relationships have created international expansion opportunities. A variety of firms, many of them major western companies, approached the CP Group to join them in ventures throughout Asia (Pananond and Zeithaml, 1997). Whereas the CP Group provided the market knowledge, the other partner supplied the product or technology. While product/ technology-based firms prefer to excel in a limited number of industries and extend that expertise to foreign markets through direct investments, knowledge-based firms with a superior understanding of the markets (e.g. the $\mathrm{CP}$ Group) prefer to exploit their advantage through diversification into markets that may not always be related.

Finally, Chinese business firms from Southeast Asia develop their competitive advantage through strategic investments in the Triad countries. By investing in key technologically-sophisticated economies (e.g. the USA and western Europe), these Chinese business firms are able to obtain know-how and technology. These host countries also provide useful 'training grounds' for the firm's personnel to experience new management and marketing practices. For example, Dr Veerawat Kanchanadul, Executive Vice President of the CP Group, explained:

Our reasons to invest in Europe or the US are first to gain technological and managerial skills; then it is to learn about the development trend of that particular industry. We can learn in countries where those industries are mature and already developed. We learned that feedmill industries would not survive by itself, they need to be vertically integrated. So we were the first in Thailand to start an integrated farm when everyone else was still against such a concept. And now, everyone is following us (Quoted in Pananond and Zeithaml, 1997: 21).

\section{Conclusions and implications for research}

This paper has explored some aspects of the internationalization of ethnic Chinese business firms from Southeast Asia. Through selected case studies, it has been shown that the internationalization of these firms is largely explained by the changing global competitive context and local institutional conditions as well as firm-specific strategies. Internationalization occurs as a result of their diversification strategies in view of limited domestic markets and persistent ethnic-inspired discrimination. Moreover, as Chinese 
business firms in Southeast Asian countries are consolidating their domestic positions, it is expected that they will continue to expand geographically in search of new markets and production sites. Although their transnational operations still largely concentrate within the Asia Pacific region, Chinese business firms are expected to venture more aggressively in future into the Triad countries, particularly in North America and western Europe. Many Hong Kong and Taiwanese Chinese firms have already established strong footholds in North America and western Europe (see Yeung, 1994b; Mitchell, 1995; Olds, 1999; Yeung and Olds, 1999).

It must be noted, however, that existing research into the internationalization of Chinese business firms is still very limited (see Yeung and Olds, 1999). This paper generates more questions than answers. A tentative research agenda is thus proposed here. First, more research attention should be paid to the changing nature and organization of Chinese business firms when they operate across national boundaries. To what extent are Chinese business firms similar to or different from other firms in their home as well as host countries? Will family control and ownership continue to be the defining characteristic of Chinese business firms in the international context? What adjustments do these ethnic Chinese firms need to make in order to compete successfully in the host countries?

Second, the international transferability of their competitive advantages remains integral to our understanding of the success of Chinese business firms abroad. Given their enormous success in Southeast Asian countries, is it possible for them to transfer their business networks and peculiar practices to countries outside Asia? Are their sources of competitive advantage contingent upon the unique circumstances in Southeast Asia, or are they generalizable to other social and institutional settings? What are the institutional constraints faced by them in trying to penetrate foreign markets? How can they compete effectively with technologically-sophisticated global corporations from the Triad countries?

Third, it is equally important to investigate how these Chinese business firms overcome inherent limits to their growth. In the literature on Chinese family firms, there is a debate over the limits to their growth. Some management experts believe that reliance on family members to take over top management in Chinese business effectively limits the firm's expansionary trajectories (e.g. Redding, 1980; 1990; Kao, 1993; Chen, 1995). A fundamental research question is whether Chinese business firms can experience growth along with continued family control and ownership. Some anecdotal evidence suggests that Chinese family firms can achieve growth through internationalization (Yeung, 1997c). It appears that the worldwide web of Chinese business is still in the process of development. It will take many more years for these business firms to extend successfully their global reach and for academic researchers to grasp fully the complex issues generated by their internationalization tendencies.

Henry Wai-Chung Yeung (geoywc@nus.edu.sg), Department of Geography, National University of Singapore, 10 Kent Ridge Crescent, 119260 Singapore.

\section{References}

Aggarwal, R. (ed.) (forthcoming) Special issue on multinationals from emerging countries. International Business Review 6.

Ariff, M. and J.L.H. Tan (1992) Introduction. ASEAN Economic Bulletin 8, 251-7.

Blim, M. (1996) Cultures and the problems of capitalisms. Critique of Anthropology 16, 79-93.

Braadbaart, O. (1995) Sources of ethnic advantages: a comparison of Chinese and pribumimanaged engineering firms in Indonesia. In R.A. Brown (ed.), Chinese Business Enterprise in Asia, Routledge, London.

Brown, R.A. (ed.) (1995) Chinese business enterprise in Asia. Routledge, London. 
(1998) Overseas Chinese investments in China - patterns of growth, diversification and finance: the case of Charoen Pokphand. The China Quarterly 155, 610-36.

Chan, K.B. and S.N.C. Chiang (1994) Stepping out: the making of Chinese entrepreneurs. Simon and Schuster, Singapore.

Chan, W.K.K. (1995) The origins and early years of the Wing On Company Group in Australia, Fiji, Hong Kong and Shanghai: organisation and strategy of a new enterprise. In R.A. Brown (ed.), Chinese Business Enterprise in Asia, Routledge, London.

Chen, D.C. (1976) Social and economic relations of overseas Chinese business. PhD Dissertation, University Microfilms International, Ann Arbor, Michigan.

Chen, M. (1995) Asian management systems: Chinese, Japanese and Korean styles of business. Routledge, London.

Chen, X. (1994) The new spatial division of labor and commodity chains in the Greater South China Economic Region. In G. Gereffi and M. Korzeniewicz (eds.), Commodity chains and global capitalism, Praeger, Westport, Connecticut.

Dicken, P. (1998) Global shift: transforming the world economy. Paul Chapman, London.

Dirlik, A. (1997) Critical reflections on "Chinese capitalism" as paradigm. Identities 3, 303-30.

East Asia Analytical Unit (1995) Overseas Chinese business networks in Asia. Department of Foreign Affairs and Trade, Parkes, Australia.

Economist Intelligence Unit (1995) EIU country report. EIU, London.

Goldberg, M.A. (1985) The Chinese connection: getting plugged in to Pacific Rim real estate, trade, and capital markets. University of British Columbia Press, Vancouver.

Greenhalgh, S. (1994) De-orientalizing the Chinese family firm. American Ethnologist 21, 746-75.

Guo, J.J. (1993) The role of Taiwan in the Asia-Pacific community. In K.S. Liao (ed.), Politics of economic cooperation in the Asia-Pacific region, Chinese University of Hong Kong Press, Hong Kong.

Hamilton, G.G. (1991) The organizational foundation of western and Chinese commerce: a historical and comparative analysis. In G.G. Hamilton (ed.), Business networks and economic development in East and South East Asia, Centre of Asian Studies, University of Hong Kong, Hong Kong.

- (1996a) Competition and organization: a re-examination of Chinese business practices. Journal of Asian Business 12, 7-20.

- (1996b) Overseas Chinese capitalism. In W.M. Tu (ed.), Confucian traditions in East Asian modernity: moral education and economic culture in Japan and the four mini-dragons, Harvard University Press, Cambridge, MA.

— and T. Waters (1995) Chinese capitalism in Thailand: embedded networks and industrial structure. In E.K.Y. Chen and P. Drysdale (eds.), Corporate links and foreign direct investment in Asia and the Pacific, Harper Educational, New South Wales.

Hodder, R. (1996) Merchant princes of the East: cultural delusions, economic success and the overseas Chinese in Southeast Asia. John Wiley, Chichester.

Hsiao, M.H.H. and A. So (1997) The Chinese triangle and the future of the Asia-Pacific region, Westview, Boulder, CO.

Hsing, Y.T. (1997) Making capitalism in China: The Taiwan connection. Oxford University Press, New York.

$\mathrm{Hu}$, Y.S. (1995) The international transferability of the firm's advantages. California Management Review 37, 73-88.

International Monetary Fund (1995) International financial statistics. IMF, Washington.

Jesudason, J.V. (1989) Ethnicity and the economy: the state, Chinese business and multinationals in Malaysia. Oxford University Press, Singapore.

- (1997) Chinese business and ethnic equilibrium in Malaysia. Development and Change 28, $119-41$.

Jomo, K.S. (1988) A question of class: capital, the state, and uneven development in Malaya. Monthly Review Press, New York.

Kao, J. (1993) The worldwide web of Chinese business. Harvard Business Review March-April, 24-36.

Khan, K.M. (ed.) (1986) Multinationals of the South: new actors in the international economy. Frances Pinter Publishers, London.

Kim, T.J., G. Knaap and I. Azis (1992) Spatial development in Indonesia: review and prospects. Avebury, Aldershot. 
Koike, K. (1993) Introduction. The Developing Economies 31, 363-77.

Kraar, L. (1993) Importance of Chinese in Asian business. Journal of Asian Business 9, 87-94.

Kumar, K. and M.G. McLeod (eds.) (1981) Multinationals from developing countries. D.C. Heath, Lexington.

La Croix, S.J., M. Plummer and K. Lee (eds.) (1995) Emerging patterns of East Asian investment in China: from Korea, Taiwan, and Hong Kong. M.E. Sharpe, Armonk.

Lall, S. (1983) The new multinationals: the spread of third world enterprises. Wiley, Chichester.

Lévy, B. (1995) Globalization and regionalization: toward the shaping of a tripolar world economy? The International Executive 37, 349-71.

Lim, L.Y.C. (1996) The evolution of Southeast Asian business systems. Journal of Southeast Asia Business 12, 51-74.

_ and L.A.P. Gosling (eds.) (1983) The Chinese in Southeast Asia. Maruzen Asia, Singapore.

Limlingan, V.S. (1986) The overseas Chinese in ASEAN: Business strategies and management practices. Vita Development Corporation, Manila.

Mackie, J.A.C. (1988) Changing economic roles and ethnic identities of the Southeast Chinese: a comparison of Indonesia and Thailand. In J.W. Cushman and G.W. Wang (eds.), Changing identities of the Southeast Asian Chinese since world war II, Hong Kong University Press, Hong Kong.

Menkhoff, T. (1993) Trade routes, trust and trading networks - Chinese small enterprises in Singapore. Verlag breitenback Publishers, Saarbrucken.

Mitchell, K. (1995) Flexible circulation in the Pacific Rim: capitalism in cultural context. Economic Geography 71, 364-82.

McVey, R. (ed.) (1992) Southeast Asian capitalists. Cornell University Southeast Asia Program, Ithaca.

Ohmae, K. (1985) Triad power: the coming shape of global competition. The Free Press, New York.

- (1995) The end of the nation state: the rise of regional economies. Harper Collins, London.

Olds, K. (1999) Globalization and urban change: capital, culture and Pacific Rim mega projects. Oxford University Press, New York.

— and H.W.C. Yeung (1999) Reshaping "Chinese" business networks in a globalising era. Environment and Planning D: Society and Space 17.

Palanca, E.H. (1995) Chinese business families in the Philippines since the 1890s. In R.A. Brown (ed.), Chinese business enterprise in Asia, Routledge, London.

Pananond, P. and C.P. Zeithaml (1997) The international expansion process of MNEs from developing countries: a model and empirical evidence. Paper presented at the Asian Pacific Journal of Management Conference, National University of Singapore, 27-28 February.

Porter, M.E. (1985) Competitive advantage: creating and sustaining superior performance. The Free Press, New York.

Redding, S.G. (1980) Cognition as an aspect of culture and its relation to management process: an exploratory review of the Chinese case. Journal of Management Studies 17, 127-48. (1990) The spirit of Chinese capitalism. De Gruyter, Berlin.

- (1995) Overseas Chinese networks: understanding the enigma. Long Range Planning 28, 61-9. (1996) Societal transformation and the contribution of authority relations and cooperation norms in overseas Chinese business. In W.M. Tu (ed.), Confucian traditions in east Asian modernity: moral education and economic culture in Japan and the four mini-dragons, Harvard University Press, Cambridge, MA.

Robison, R. (1986) Indonesia: the rise of capital. Allen \& Unwin, Sydney.

Rodan, G. (1989) The political economy of Singapore's industralization: nation state and international capital. Forum, Kuala Lumpur.

Sato, Y. (1993) The Salim Group in Indonesia: the development and behaviour of the largest conglomerate in Southeast Asia. The Developing Economies 31, 408-41.

Shikatani, T. (1995) Corporate finances of overseas Chinese financial groups. Nomura Research Institute Quarterly 4, 68-91.

Smart, A. (1997) Capitalist story-telling and hegemonic crises: some comments. Identities 3, 399412.

Smart, J. and A. Smart (1991) Personal relations and divergent economies: a case study of Hong Kong investment in South China. International Journal of Urban and Regional Research 15, 216-33. 
Suehiro, A. (1985) Capital accumulation and industrial development in Thailand. Chulalongkorn University Social Research Institute, Bangkok.

(1992) Capitalist development in postwar Thailand: commercial bankers, industrial elites, and agribusiness groups. In R. McVey (ed.), Southeast Asian capitalists, Cornell University Southeast Asia Program, Ithaca.

- (1993) Family business reassessed: corporate structure and late-starting industrialization in Thailand. The Developing Economies 31, 378-407.

Suryadinata, L. (1988) Chinese economic elites in Indonesia: a preliminary study. In J.W. Cushman and G.W. Wang (eds.), Changing identities of the Southeast Asian Chinese since world war II, Hong Kong University Press, Hong Kong.

The Sunday Times (1997) Acumen can be learnt, says tycoon. 2 February, Singapore.

The Straits Times (1997) S'poreans 'can be world-class hoteliers'. 29 October, Singapore.

Tolentino, P.E.E. (1993) Technological innovation and third world multinationals. Routledge, London.

UNCTAD (1994) World investment report 1994: transnational corporations, employment and the workplace. United Nations, New York.

(1996) World investment report 1996. United Nations, New York.

Van Den Bulcke, D. and H.Y. Zhang (1995) Chinese family-owned multinationals in the Philippines and the internationalisation process. In R.A. Brown (ed.), Chinese business enterprise in Asia, Routledge, London.

Weidenbaum, M. and S. Hughes (1996) The bambook network: how expatriate Chinese entrepreneurs are creating a new economic superpower in Asia. The Free Press, New York.

Wells, L.T. Jr. (1983) Third world multinationals: the rise of foreign investment from developing countries. The M.I.T. Press, Cambridge, MA.

Whitley, R. (1992) Business systems in East Asia: firms, markets and societies. Sage, London.

Whyte, M.K. (1996) The Chinese family and economic development: obstacle or engine? Economic Development and Cultural Change 45, 1-30.

Wu, F. and S.Y. Duk (1995) Hong Kong and Singapore: "twin capitals" for overseas Chinese capital. Business \& The Contemporary World 7, 21-33.

Yeung, H.W.C. (1994a) Third world multinationals revisited: a research critique and future agenda. Third World Quarterly 15, 297-317.

- (1994b) Transnational corporations from Asian developing countries: their characteristics and competitive edge. Journal of Asian Business 10, 17-58.

_ (1997a) Business networks and transnational corporations: a study of Hong Kong firms in the ASEAN region. Economic Geography 73, 1-25.

- (1997b) Cooperative strategies and Chinese business networks: a study of Hong Kong transnational corporations in the ASEAN region. In P.W. Beamish and J.P. Killing (eds.), Cooperative strategies: Asia-Pacific perspectives, The New Lexington Press, San Francisco, CA.

(1997c) Limits to the growth of family-owned business? The case of Chinese transnational corporations from Hong Kong. Proceedings of the Academy of International Business Asia Pacific Area Conference, University of Hawaii, 19-21 June.

(1998a) The political economy of transnational corporations: a study of the regionalisation of Singaporean firms. Political Geography 17, 389-416.

- (1998b) Transnational corporations and business networks: Hong Kong firms in the ASEAN region. Routledge, London.

_ (1999a) The globalisation of business firms from emerging economies. Edward Elgar, Cheltenham.

(1999b) Under siege? Economic globalization and Chinese business in Southeast Asia. Economy and Society 28, 1-31.

(1999c) Regulating investment abroad? The political economy of the regionalisation of Singapore firms. Antipode 31.

- and K. Olds (eds.) (1999) The globalisation of Chinese business firms. Macmillan, London. Yoshihara, K. (1985) Philippine industrialization: foreign and domestic capital. Oxford University Press, Singapore.

_ (1988) The rise of ersatz capitalism in South East Asia. Oxford University Press, Singapore. (1994) The nation and economic growth: The Philippines and Thailand. Oxford University Press, Singapore. 